\title{
Search for alternative plant raw materials for food industry and environmentally safe animal breeding
}

\author{
Ekaterina V. Solomonova ${ }^{1 *}$, Nikolay A. Trusov ${ }^{2}$, Tatiana D. Nozdrina ${ }^{3}$ \\ ${ }^{1}$ Moscow educational complex WEST, Moscow, Russian Federation \\ ${ }^{2}$ Tsytsin Main Moscow Botanical Garden of Russian Academy of Sciences, \\ Moscow, Russian Federation \\ ${ }^{3}$ Moscow State University of Food Production, Moscow, Russian Federation \\ *Corresponding author: solomonova_k@mail.ru
}

\begin{abstract}
The relevance of the search for alternative plant raw materials to enrich the diets of population throughout the world, including in the Russian Federation, is explained by global mass year-round insufficiency of biologically active nutrients in food. This work is aimed at identifying the most promising food plant species from the list, proposed on basis of long-term observations by staff of Tsytsin Main Moscow Botanical Garden of Russian Academy of Sciences (MBG RAS), by bachelors, studying in direction 06.03.01 (Biology) at Moscow State University of Food Production. The research materials (2016-2018) are fruits of hawthorns, rosehips, quince, eleutherococcuses, medlar, mahonia, spindle tree, yews, sumacs, oaks, red-fruited honeysuckles and needles of coniferous plants. Research results indicate the value of studied raw materials as a whole and its advantages in compared species within the genus of plants. Some recommendations for practical usage were made. The following things have been proposed: separation of fruit pulp and seeds before drying of fruits of Crataegus submollis and more preferable C. punctata; wide plantation cultivation of rosehips Rosa amblyotis and R. oxyodon; non-waste separate application of pericarp and seeds of Cydonia oblonga, Mespilus germanica and Mahonia aquifolium; medicinal use of fruits of Eleutherococcus sessiliflorus, and more preferable E. senticosus; further study of cones of Taxus baccata and T. $\times$ media; as a spice there is usage of fruits of Rhus typhina; obtaining unique oils from fruit pulp of Lonicera glehnii, L. ferdinandii, L. maackii and arils of Euonymus europaeus; usage of acorns of Quercus robur, Q. rubra and needles of Picea abies, Pinus sylvestris in feed production. Thus, possibilities of intensifying plant resource usage in the food industry and agriculture were discovered, primarily due to fruits of native introduced species. It is necessary to continue search and further study of the most promising species — sources of alternative plant raw materials.
\end{abstract}

Key words: alternative plant raw materials, fruits, introduced species

Conflicts of interest. The authors declared no conflicts of interest.

Article history:

Received: 28 July 2020. Accepted: 28 December 2020

(C) Solomonova E.V., Trusov N.A., Nozdrina T.D., 2021

This work is licensed under a Creative Commons Attribution 4.0 International License https://creativecommons.org/licenses/by/4.0/1 


\section{For citation:}

Solomonova EV, Trusov NA, Nozdrina TD. Search for alternative plant raw materials for food industry and environmentally safe animal breeding. RUDN Journal of Agronomy and Animal Industries. 2021; 16(1):18-29. doi: 10.22363/2312-797X-2021-16-1-18-29

\section{Introduction}

The importance of search for new sources of high-quality food raw materials has a state level. It is associated with a lack of vitamins and micronutrients in food of Russian population, with problems of import substitution.

Currently, lack of various nutrients in diets is a global world problem. Significant deterioration of the environment over the past 100...150 years has led to emergence of extensive biogeochemical provinces with a low content of trace elements in drinking water, in plant and animal products. The content of ascorbic acid in domestic fruits and vegetables has not changed over the last 70 years [1]. However, vitamin $\mathrm{C}$ deficiency is found in $60 . .80 \%$ of Russians, and scurvy still can lead to death in some countries [2, 3]. Monitoring the level of other vitamins in the blood of Russians in 2015-2016 revealed a lack of vitamin D in $57.5 \%$ of adult working-age population, B vitamins in 12.6...34.5\%, carotenoids and tocopherols — in 5.3...10.8 \%, three or more vitamins - in 22...38 \% [4]. Only $10 \%$ of Russian's population is fully provided with vitamins [5]. In addition, $80 \%$ of humanity experiences a lack of dietary fiber in their diet. The population of Russian Federation receives only $60 . .65 \%$ of fiber, and only due to use of vegetables, fruits and wholemeal flour [6].

The causes of mass and year-round lack of vitamins were revealed: reduction of incoming food's volume at physiological raise standards of consumption of many vitamins; use of highly refined foods; the inability of organism to accumulate many vitamins; unbalanced diets; loss of vitamins during cooking of products; bad habits, etc. [7].

State regulates the introduction of vitamin-mineral complexes in therapeutic diets in a dose of $50 \ldots 100 \%$ of physiological norm of consumption ${ }^{1}$. However, this measure is not sufficient to correct the current situation. Undoubtedly, search for other possibilities of enriching food with necessary nutrients in Russia is relevant. Plant fruits are characterized by high content of dietary supplements, so they should be tested and studied as food raw materials in the first place.

It is promising to use vitamins and minerals in the form of vitamin-mineral complexes, or for enrichment of food products of mass consumption $[4,7,8]$. Unfortunately, at present, only foreign vitamin substances are used mainly in medicine, agriculture and food production [4]. In accordance with Russian Federation's policy, aimed at import substitution, the maximum use of nutritional potential of domestic plants, both natural and introduced species, is required.

Safe, environmentally friendly, alternative raw materials of plant origin, including those from fruits of wild plants, are not involved widely yet in economic-food turnover [9-12]. However, «the integrated use of plant raw materials based on a rational

\footnotetext{
${ }^{1}$ The act of the ministries and departments «On the approval of the norms of medical nutrition» dated 21.06. 2013 № 395n.
} 
combination of traditional and non-traditional types of raw materials ... and creation of technologies for production of qualitatively new food products» is provided according to the «Concept of the state policy in the field of healthy nutrition of the Russian Federation population for the period until 2020».

Along with foregoing, development of ecologically pure animal husbandries branch is required to saturate diet of Russians with necessary biologically safe nutrients. Cultivated animals should be provided with high-quality plant foods with high content of vitamins, trace elements and dietary fiber. To solve this problem, plant raw materials inedible for humans, such as needles, acorns, etc., also can be considered.

It is known that both vegetative and generative parts of plants accumulate substances, including biologically active ones, differently. In addition to the differences in biochemistry and ash content of different parts of perennial plants, there are other, «technological», features of their food and medicinal use.

Vegetative organs (stems, roots, leaves) are not as unique in chemical composition as generative ones. In perennial plants, without injuring them, only leaves can be collected and used annually. Lignified stems, roots and rhizomes are difficult to renew, although sometimes they are valuable resource, such as, for example, at Eleutherococcus senticosus.

Generative organs of plants are flowers and fruits. They, like leaves, are easily renewable, seasonal, usually annual resources, but of increased biochemical value. Flowers, unlike fruits, are often insignificant in biomass. Fruits of the plant kingdom are diverse in structure types, shape, size and other characteristics. Functioning of fruits is closely related to their morphology and anatomy. On the basis of fruits botanical assessment through their careful, scrupulous, fundamental study through microscopy, measurements and weighing, it is possible to draw conclusions about nature, localization and abundance of substances, accumulated in fruit and its components. Obtaining the model of developing and mature fruit is necessary to solve practical problems in optimizing of deadlines collecting raw materials, identifying possibilities of most appropriate and full use of it, as well as plant breeding, for example, to increase size of most valuable fruit parts.

Thus, classical botanical study of plant raw materials and, especially, fruits, with parallel biochemical testing, is relevant and promising in food and agronomic universities.

\section{Materials and methods}

As part of valuable plants fruits study, fruitful cooperation between Moscow State University of Food Production and Tsytsin Main Moscow Botanical Garden of Russian Academy of Sciences (MBG RAS). MBG RAS has a huge collection of introduced species, vegetating and bearing in central Russia. In particular, in the arboretum of MBG RAS, plants are arranged according to systematic principles. Representatives of each genus are grown on one exposure, under the same conditions. This makes it possible to compare plants and their fruits.

To conduct research on collections of potentially valuable food plants, a «working resource» is needed. In our case, these are bachelors, studying in direction 
06.03.01 — Biology, who received basic knowledge in botany, plant physiology, and environmental disciplines, understanding basic principles of fruit structure.

According to the standard low-cost scheme for studying fruits by morphological and anatomical structure, size and weight indicators, testing for vitamin $\mathrm{C}$, students identified the most promising alternative to traditional plant species as plant biologically safe raw materials from list, proposed on basis of long-term observations by employees of MBG RAS.

For a number of years (2016 - 2018), the fruits of hawthorns, rosehips and quince were studied as alternative to fruits of traditional pome trees; fruits of eleutherococcuses as edible and at the same time medicinal; rich in ascorbic acid fruits of exotic medlar and mahonia, introduced in central Russia; promising oil-bearing fruits of red-fruited honeysuckles and spindle tree; yew fruits with edible arils; sumac fruits used as spices; fruits of oaks and needles of coniferous plants as raw materials for animal feed [13-19].

\section{Research results of woody plants resource potential}

Analysis of literature showed that plants that were closely related to objects of our research were cultivated in a number of countries (rarely or never in the Russian Federation) because of edible, sometimes even medicinal fruits, rich in biologically active substances.

Hawthorns. Fruits of two species were studied: Crataegus submollis Sarg. and C. punctata Jacq.

Content of vitamin $\mathrm{C}$ in dried raw materials was determined. Fruits of $C$. submollis were most rich in ascorbic acid; only 109 g contain daily dose of vitamin C.

Results obtained by us allowed recommending the following fruit species successfully introduced in Moscow region: C. punctata and C. submollis for widespread use the in the food industry and feed production. Fruits of $C$. submollis were more preferable in raw quality, because in comparison with fruits of $C$. punctata, they were larger $(19 \times 17 \mathrm{~mm}$ against $16 \times 17 \mathrm{~mm}$, respectively); proportion of pericarp was higher in absolutely dry fruits of $C$. submollis (92 \% against $85 \%$, respectively), proportion of stones, conversely, was lower (85 \% against $89 \%$, respectively); and they were also better in organoleptic characteristics (taste, smell, texture).

During morphological and anatomical study of hawthorn fruits it was revealed that stones were covered with a stony coat. In case of raw material procurement for feed production, it is proposed to separate fruit pulp from stones, which can ulcerate the gastrointestinal tract of animals. It was found that separation was easy to implement only in fresh fruits, before their drying.

Rosehips. Fruits of three rosehips species, that have been preserved long on plants have been studied: Rosa amblyotis C.A. Mey, R. oxyodon Boiss. and R. maximowicziana Regel. Superiority of infructescence of $R$. amblyotis and $R$. oxyodon over infructescence of $R$. maximowicziana was established by following parameters: larger and more massive infructescence, more powerful hypanthium, higher content of ascorbic acid (4180, 2200 and $880 \mathrm{mg} \%$, respectively). It is important that in terms of content of vitamin C, $R$. amblyotis and $R$. oxyodon are not inferior to species of rosehips, that are currently used in food and pharmaceutical industries. 
Performed comparative complex morphological and anatomical, and biochemical researches allow us to recommend new promising species of rosehips for plantation cultivation in central Russia and implementation in industrial production: $R$. amblyotis and $R$. oxyodon. Both species are well adapted to appropriate environmental and climatic conditions, their fruits have advantages for use in the food industry.

Quince. Comparison of fruits of C. oblonga from the arboretum of MBG RAS with imported ones from free sale was made.

High content of ascorbic acid in fruits of $C$. oblonga was determined, approximately the same in fruits of compared samples. Only $33 \mathrm{~g}$ of fruits contains a daily dose of vitamin C.

It was also established that seeds of $C$. oblonga, collected at MBG RAS, contain oils (15.8\%), which indicates the prospects of their use as a source of fatty oils.

Nutritional use of fruits of $C$. oblonga can be non-waste, because both pericarp and seeds are rich in biologically active substances; there is a possibility of additional extraction of oils from oilcake after using the fruit pulp.

Infection of imported raw materials with fungal hyphae was detected (in fruit nests).

Thus, the competitiveness and economic benefits of using in the food industry significantly smaller fruits of introduced C. oblonga in comparison with imported fruits were shown.

Eleutherococcuses. Fruits of Eleutherococcus senticosus (Rupr. \& Maxim.) Maxim. and E. sessiliflorus (Rupr. \& Maxim.) S.Y. Hu were investigated.

At the moment, only roots of these plants are actively used as medicines. According to literature, fruits of Eleutherococcus are also rich in various biologically active substances, including valuable adaptogens - eleutherosides.

We found out that fruits of E. senticosus and E. sessiliflorus contained $0.3 \mathrm{~g}$ and $0.27 \mathrm{~g}$ of ascorbic acid, respectively. Advantages of using E. senticosus in the breeding and food industry were revealed, considering ratio of fruit pulp to fruit volume.

Medlar. Taste and biochemical features, that determine them, in fruits of introduced Mespilus germanica L. were revealed. Significant content of ascorbic acid was found. Only $190 \mathrm{~g}$ of dried fruit is able to make up for daily norm of vitamin C. According to literature, mature medlar fruits from more favorable growing conditions contain approximately the same amount of ascorbic acid, in addition to natural antioxidants, anti-radiants, carotenoids, pectin and bioflavonoids.

We determined that stones of fruits, grown in Moscow region conditions, occupied about $45 \%$ of fruit volume. Value of unique «antiaging» oils, obtained from them, involves cultivation of $M$. germanica in central Russia, primarily for use in cosmetics industry. In case of separate using of fruits pulp in food industry, and stones - in cosmetology, it is recommended to separate them from each other in fresh fruits before drying raw materials.

Mahonia. Content of vitamin C in one fruit of Mahonia aquifolium (Pursh) Nutt., reaching 109.5 mcg, was determined. According to literature, the plant is medicinal, due to the content of alkaloids berberine and berbamine; fruits are edible. Presumably, water-soluble vitamin $\mathrm{C}$ and alkaloids are extracted from raw materials together; it is probably that therapeutic effect of berberine and berbamine is enhanced by even a small amount of ascorbic acid. 
Oil content of seeds of $M$. aquifolium was determined, on average $8.7 \%$ of the total weight of one seed. Thus, not only pericarp, but also seeds, interesting as a source of essential fatty acids, are valuable in the fruit of mahonia.

Seeing large yield and high resistance of this species to environmental factors, it is possible to consider using of fruits pulp and seeds of $M$. aquifolium in industrial model of non-waste production.

Yews. Cones of three species of yews were studied — Taxus baccata L., T. × media and T. canadensis Marshall.

In study of anatomical structure of arils and seeds, we did not reveal significant differences.

It was found that $T . \times$ media cones were the largest, $T$. canadensis cones were the smallest. Cones of $T$. baccata occupy middle position among studied species. Comparison with literary sources showed that galberries of T. baccata, collected in an arboretum of MBG RAS, were superior in length and diameter to those, growing in natural conditions.

It was found that arils of $T$. baccata and T.×media were superior to $T$. canadensis arils in their sizes and content of dry matter in cones.

Using of yews arils like food or medicine, as in some foreign countries, may have a positive effect on the organism generally, due to content of vitamins, carotenoids and organic acids, necessary to person. For further study, we recommend species $T$. $\times$ media and T. baccata, because their arils proved more promising raw material for creature of nutritive products than $T$. canadensis's arils.

Sumac. Objects of research were fruits of Rhus typhina L., in comparison with dried, crushed fruits of $R$. coriaria L., purchased in free sale in form of spice «sumac».

Organoleptic evaluation of two species of sumac did not reveal differences between them, with exception to color.

Similarity of morphological and anatomical structure of fruits of two species was revealed.

During analysis of size and weight parameters of fruits, as well as corresponding literature data, it was found that fruits of $R$. coriaria were $17 . . .33 \%$ larger than fruits of R. typhina.

Amounts of vitamin C (62...65 mg\%) determined and absolutely dry matter in airdry $(91 . .97 \%)$ in $R$. coriaria fruits slightly exceeded similar parameters in $R$. typhina fruits, which allowed us to conclude biochemical similarity of raw materials from fruits of both species.

We found a high degree of conformity of $R$. typhina fruits to $R$. coriaria fruits in many ways, which means potential application of $R$. typhina's fruits as spice in the food industry. Considering possibilities of cultivating of $R$. typhina on industrial scale under conditions of introduction, including territory of Moscow and Moscow Region, $R$. typhina may be more beneficial to use than its competitor $-R$. coriaria.

\section{Research results of alternative oil plants}

Red-fruited honeysuckles. Fruits of red-fruited honeysuckles of three species were studied: Lonicera glehnii F. Schmidt, L. ferdinandii Franch and L. maackii (Rupr.) Maxim., as potential new sources of plant oils. 
Red-fruited honeysuckles is not commonly regarded as fruit plant, since berries of all their species are inedible, even poisonous. According to published data, pericarp of red honeysuckles possesses a large number of carotenoids and tocopherols, extracted together with non-toxic lipid fraction of unique fatty acid composition, which can serve as dyes and valuable vitamin nutritional supplements. Our studies have confirmed abundance of oil inclusions not only in seeds cells, but also in pericarps cells of L. glehnii, L. ferdinandii and L. maackii. Quantity of crude oil in fruits is in range of 4.47...15.69 \%. It was found, that fruits of studied honeysuckles species possessed an insignificant supply of ascorbic acid.

Spindle tree. Fruits of Euonymus europaeus L. were investigated. The main feature of spindle tree fruits, in our opinion, is their oil content. Fatty oils of arils (content of oil more than $50 \%$ ) and seeds (content of oil is $20 . .50 \%$ ) are not identical in composition. Presence of large number of oil inclusions in cells of aril, endosperm and germ was confirmed. High content of oil in arils and seeds (39 and $42 \%$, respectively) was revealed. Oil inclusions in cells of seed coat and pericarp were not detected. For the first time, content of ascorbic acid in fruits was established; the largest one — in pericarp (13.48 mcg), intermediate in arils (4.49 mcg) and the smallest one — in seeds (1.96 mcg).

Based on data obtained, spindle tree fruits can be used as promising oilseed raw materials for non-waste production: it is possible to obtain oils from arils and seeds, and ascorbic acid from pericarp.

\section{Research results of plant raw materials for fodder additives}

Oaks. The fruits (acorns) of 2 species of oaks: natural Quercus robur L. and introduced species - Q. rubra L., were investigated.

It was found, that mass of inedible pericarp (shell) with respect to mass of entire fruit was 16.19 and $36.91 \%$ for Q. robur and Q. rubra, respectively, which corresponded to literature. Content of absolutely dry matter in fruits of Q. robur (96.25\%) and Q. rubra (95.75\%) was determined.

It was found that content of ascorbic acid in terms of daily dose in fruits of compared samples was different. One acorn of $Q$. robur contained on average $0.054 \mathrm{~g}$ of vitamin C, and one acorn of Q. rubra - $0.047 \mathrm{~g}$.

Thus, possibilities of using their fruits as source of starch, vitamins, oils and other nutrients were identified. Despite the fact, that according to results of our research, fruits of $Q$. rubra are inferior to fruits of $Q$. robur in all respects, it is recommended by us to consider acorns of both plants as raw materials for fodder production and creation of biologically active additives.

Coniferous plants. In Russia, volume of forest organic matter, used in harvesting and processing of forest, significantly exceeds volume of waste, unused during this.

We agree with authors who regard forest resources as additional fodder base for animal husbandry, due to natural renewability, impressive amount, accessibility and the possibility of year-round use.

In addition, according to European standards, feed crops, grown without use of pesticides, herbicides and mineral fertilizers are necessary to obtain environmentally 
friendly livestock products. Coniferous plants of the forest part of Russian Federation correspond to these requirements.

Coniferous shoots of Picea abies (L.) H. Karst., Pinus sylvestris L., and Juniperus communis L. were selected as objects of our research.

It was shown, that mass of needles per $1 \mathrm{~cm}$ of shoot in $P$. sylvestris was the largest one $(0.46 \mathrm{~g} / \mathrm{cm})$, while needles of $P$. abies and $J$. communis contained more ascorbic acid (0.76 and $0.73 \mathrm{mg} \%$, respectively).

Currently, coniferous shoots of $P$. abies and $P$. sylvestris coniferous plants are logging waste and are not included in economic turnover. At the same time, they are promising for use in environmentally friendly livestock and food industries.

\section{Conclusion}

According to literature, 700...1000 species of wild fruit plants grow in Russia. Despite the richness of their fruits with natural antioxidants, anti-radiants, pectin, bioflavonoids and vitamins A, E and C, only about 50 plant species are used in food production.

Harvesting raw materials from wild plants in natural habitats is difficult for technical and environmental-biological reasons: geographical remoteness and scattered arrangement of some plant species, lack of roads, need to comply with collection regulations, etc. Alternative is plantation cultivation of valuable plants in nurseries.

Most promising species according to results of comprehensive assessment can be the basis for cultivation - introduced species from world flora of fruit plants, presented in collections of Russian botanical gardens.

Fruits of local plants are often not inferior to raw materials imported from abroad in terms of biochemical characteristics (vitamin C content, oil content) and absolutely dry matter, although they can lose in size of fresh fruits. Thus, possibilities of intensifying use of plant resources in food industry and agriculture were discovered, primarily due to fruits of native introduced species, as well as due to forest industry waste (needles) not included in economic activity. It is necessary to continue search and further study of the most promising species. Their plantation cultivation can become an excellent alternative to import of plant materials, significantly reducing transportation, customs and storage expenses and costs of assessing its biological and sanitary safety.

\section{References}

1. Kosheleva OV, Kodentsova VM. Vitamin C in fruits and vegetables. Problems of Nutrition. 2013; 82(3):45-52. (In Russ).

2. Nikolayeva LA, Nenakhova EV. Biologicheskaya rol'vitaminov v organizme. Metody otsenki vitaminnoi obespechennosti organizma cheloveka. Metody opredeleniya vitamina S [The biological role of vitamins in the body. Methods for assessing the vitamin supply of the human body. Methods for determining vitamin C]. Irkutsk: IGMU publ.; 2014. (In Russ).

3. Rebrov VG, Gromova VA. Vitaminy, makro- i mikronutrienty [Vitamins, macro- and micronutrients]. Moscow: GEOTAR-Media publ.; 2011. (In Russ).

4. Kodentsova VM, Vrzhesinskaya OA, Risnik DV, Nikityuk DB, Tutelyan VA. Micronutrient status of population of the Russian Federation and possibility of its correction. State of the problem. Problems of Nutrition. 2017; 86(4):113-124. (In Russ). doi: 10.24411/0042-88

5. Kodentsova VM. Provision of vitamins for children and adults in the Russian Federation: current status and ways of correcting micronutrient deficiencies. In: Materialy XVI mezhdunarodnogo foruma «Pishchevye ingredienty KhKhI veka» [Proceedings of the XVI International Forum «Food Ingredients of the XXI Century»]. Moscow: NII pitania publ.; 2015. p.1-6. (In Russ). 
6. Doronin AF, Ipatova LG, Kochetkova AA. Funktsional'nye pishchevye produkty. Vvedenie v tekhnologii [Functional foods. Technology introduction]. Moscow: DeLi print publ.; 2009. (In Russ).

7. Kislukhina OV. Vitaminnye kompleksy iz rastitel'nogo syr'ya [Vitamin complexes from plant materials]. Moscow: DeLi print publ.; 2004. (In Russ).

8. Kodentseva VM, Vrzhesinskaya OA, Sokolnikov AA. Food fortification: the history and perspectives. Problems of Nutrition. 2012; 81(5):66-78. (In Russ).

9. Donchenko LV, Nadykta VD. Bezopasnost'pishchevogo syr'ya i produktov pitaniya [The safety of food raw materials and food]. Moscow: Pishchepromizdat publ.; 1999. (In Russ).

10. Matveeva TV, Koryachkina SY. Muchnye konditerskie izdeliya funktsional'nogo naznacheniya. Nauchnye osnovy, tekhnologii, retseptury [Functional flour confectionery. Scientific fundamentals, technologies, recipes. Saint Petersburg: GIORD publ.; 2015. (In Russ).

11. Bystrická J, Musilová J, Lichtnerová H, Lenková M, Kovarovič J, Chalas M. The content of total polyphenols, ascorbic acid and antioxidant activity in selected varieties of quince (Cydonia oblonga Mill.). Potravinarstvo: Slovak Journal of Food Sciences. 2017; 11(1):77_-81. doi: 10.5219/699

12. Monka A, Grygorieva O, Chlebo P, Brindza J. Morphological and antioxidant characteristics of quince (Cydonia oblonga Mill.) and chinese quince fruit (Pseudocydonia sinensis Schneid.). Potravinarstvo: Slovak Journal of Food Sciences. 2014; 8(1):333—340. doi: 10.5219/415

13. Lebedeva DD, Trusov NA, Solomonova EV, Nozdrina TD, Meer TP. Prospects for the use of coniferous plants in the Moscow region as a biosafe source of ascorbic acid. Vestnik of Kursk State Agricultural Academy. 2018; (8):31-35. (In Russ).

14. Mitrofanova DB, Solomonova EV, Trusov NA. Possibility of using yew cones in the food industry. Eurasian Scientific Association. 2018; (5-4):197-198. (In Russ).

15. Nozdrina TD, Trusov NA, Solnyshkova AA, Solomonova EV. The fruits of Euonymus as a source of oils. In: Den' nauki. Obshcheuniversitetskaya nauchnaya konferentsiya molodykh uchenykh i spetsialistov [Science Day. University Scientific Conference of Young Scientists and Specialists]. Moscow: MGUPP publ.; 2016. p.81-82. (In Russ).

16. Chernov IA, Nozdrina TD, Trusov NA, Solomonova EV. The bioresource potential of Quercus fruits for use in the food industry. Materialy VI Mezhdunarodnoi nauchno-prakticheskoi konferentsii «Problemy sovremennoi biologii», posvyashchennoi 130-letiyu so dnya rozhdeniya N.I. Vavilova [Proceedings of the VI International Scientific and Practical Conference "Problems of Modern Biology" dedicated to the 130th birthday of N.I. Vavilova]. Lugansk: LNAU publ.; 2017. p.84—85. (In Russ).

17. Solomonova EV, Trusov NA, Nozdrina TD. Opportunities for using of Eleutherococcuses fruits as a new food raw material. In: 1st International Symposium Innovations in Life Sciences (ISILS 2019). Advances in Biological Sciences Research, Volume 7. Atlantis Press; 2019. p.303-307. doi: 10.2991/isils-19.2019.73

18. Solomonova EV, Trusov NA, Nozdrina TD, Meer TP, Sorokopudov VN, Georgescu C. Food potential of alternative pome fruit trees cultivated in Moscow region. Scientific Study \& Research. Chemistry \& Chemical Engineering, Biotechnology, Food Industry. 2019; 20(4):597-607.

19. Nozdrina TD, Solomonova EV, Trusov NA. Non-traditional for Moscow region rosehips species: morphometric and gravimetric characteristics of cinarrodies. Environment and Human: Ecological Studies. 2019; 9(2):145-161. (In Russ). doi: 10.31862/2500-2961-2019-9-2-145-161.

\section{About authors:}

Solomonova Ekaterina Vladimirovna — PhD in Biology; Teacher, Moscow educational complex WEST, 23 Bobruiskaya str., Moscow, 121359, Russian Federation; e-mail: solomonova_k@mail.ru ORCID ID: 0000-0003-0061-4080

Trusov Nikolay Aleksandrovich — PhD in Biology; Senior Researcher, Laboratory of Dendrology, Tsytsin Main Moscow Botanical Garden of Russian Academy of Sciences, 4, Botanicheskaya st., Moscow, 127276, Russian Federation; e-mail: n-trusov@mail.ru

ORCID ID: 0000-0002-5147-6602

Nozdrina Tatyana Dmitrievna — PhD in Biology; Associate Professor, Department of Veterinary-sanitary Examination and Biological Safety, Institute of Veterinary, Veterinary-sanitary Examination and Agrosafety, Moscow State University of Food Production, 11, Volokolamskoe Shosse, Moscow, 125080, Russian Federation; e-mail: biomgupp@yandex.ru

ORCID ID: 0000-0003-2589-4787 


\title{
Поиск нетрадиционного растительного сырья для пищевой промышленности и экологически чистого животноводства
}

\author{
Е.В. Соломонова ${ }^{1 *}$, Н.А. Трусов², Т.Д. Ноздрина ${ }^{3}$ \\ ${ }^{1}$ Московский образовательный комплекс ЗАПАД, г. Москва, Российская Федерация \\ ${ }^{2}$ Федеральное государственное бюджетное учреждение науки Главный ботанический сад \\ им. Н.В. Цицина Российской академии наук, \\ 2. Москва, Российская Федерация \\ ${ }^{3}$ Московский государственный университет пищевых производств, \\ 2. Москва, Российская Федерация \\ *solomonova_k@mail.ru
}

\begin{abstract}
Аннотация. Актуальность поиска нетрадиционного растительного сырья для обогащения рационов населения во всем мире, в т.ч. в Российской Федерации, объясняется глобальной массовой круглогодичной недостаточностью в пище биологически активных нутриентов. Работа нацелена на выявление самых перспективных пищевых видов растений из списка, предложенного на основе многолетних наблюдений сотрудниками Главного ботанического сада им. Н.В. Цицина Российской академии наук и бакалаврами, обучающимися в Московском государственном университете пищевых производств по направлению 06.03.01. Биология. Материалы исследований (2016-2018 гг.) — плоды боярышников, шиповников, айвы, элеутерококков, мушмулы, магонии, бересклетов, тисов, сумахов, дубов, красноплодных жимолостей и хвоя хвойных растений. Для их анализа применялись стандартные незатратные методы изучения морфолого-анатомического строения, размерно-весовых показателей, тестирования на масличность и витамин С. Полученные результаты свидетельствуют о ценности изученного сырья в целом и его преимуществах у сравниваемых видов в пределах рода растений. Даны некоторые рекомендации практического использования. Предложено разделение плодовой мякоти и косточек до высушивания плодов Crataegus submollis и, предпочтительнее, C. punctata, широкое плантационное культивирование шиповников Rosa amblyotis и R. oxyodon, безотходное раздельное применение околоплодников и семян Cydonia oblonga, Mespilus germanica и Mahonia aquifolium, лекарственное применение плодов Eleutherococcus sessiliflorus и, предпочтительнее, E. senticosus, дальнейшее изучение шишкоягод Taxus baccata и T. × media, использование в качестве специи плодов Rhus typhina, получение уникальных масел из плодовой мякоти Lonicera glehnii, L. ferdinandii и L. maackii и ариллусов Eиопутиs europaeus, использование желудей Quercus robur, Q. rubra и хвои Picea abies и Pinus sylvestris в кормопроизводстве. Обнаружены возможности интенсификации использования растительных ресурсов в пищевой промышленности и сельском хозяйстве, прежде всего, за счет плодов местных интродуцированных видов. Необходимо продолжать поиск и дальнейшее изучение наиболее перспективных видов - источников нетрадиционного растительного сырья.
\end{abstract}

Ключевые слова: нетрадиционное растительное сырье, плоды, интродуцированные виды

Заявление о конфликте интересов: Авторы заявляют об отсутствии конфликта интересов.

\section{История статьи:}

Поступила в редакцию: 28 июля 2020 г. Принята к публикации: 28 декабря 2020 г.

\section{Для цитирования:}

Solomonova E.V., Trusov N.A., Nozdrina T.D. Search for alternative plant raw materials for food industry and environmentally safe animal breeding // Вестник Российского университета дружбы народов. Серия: Агрономия и животноводство. 2021. Т. 16. № 1. С. 18-29. doi: 10.22363/2312-797X-2021-16-1-18-29 


\section{Библиографический список}

1. Кошелева О.В., Коденцова В.М. Содержание витамина С в плодоовощной продукции // Вопросы питания. 2013. Т. 82. № 3. С. 45-52.

2. Николаева Л.А., Ненахова Е.В. Биологическая роль витаминов в организме. Методы оценки витаминной обеспеченности организма человека. Методы определения витамина С. Иркутск : ИГМУ, 2014.71 с.

3. Ребров В.Г., Громова В.А. Витамины, макро- и микронутриенты. М. : ГЭОТАР-Медиа, 2011. 960 с.

4. Коденцова В.М., Вржесинская О.А., Рисник Д.В., Никитюк Д.Б., Тутельян В.А. Обеспеченность населения России микронутриентами и возможности ее коррекции. Состояние проблемы // Вопросы питания. 2017. Т. 86. № 4. С. 113-124. doi: 10.24411/0042-88

5. Коденцова B.M. Обеспеченность витаминами детского и взрослого населения РФ: современное состояние и пути коррекции дефицитов микронутриентов // Материалы XVI международного форума «Пищевые ингредиенты XXI века». М. : ФГБНУ «НИИ питания», 2015. С. 1-6.

6. Доронин А.Ф., Ипатова Л.Г., Кочеткова А.А. Функциональные пищевые продукты. Введение в технологии. М. : ДеЛи принт, 2009. 286 с.

7. Кислухина О.В. Витаминные комплексы из растительного сырья. М. : ДеЛи принт, 2004. 307 с.

8. Коденцева В.М., Вржесинская О.А., Сокольников А.А. Витаминизация пищевых продуктов массового потребления: история и перспективы // Вопросы питания. 2012. Т. 81. № 5. С. 66-78.

9. Донченко Л.В., Надыкта В.Д. Безопасность пищевого сырья и продуктов питания. М. : Пищепромиздат, 1999. 352 с.

10. Матвеева Т.В., Корячкина С.Я. Мучные кондитерские изделия функционального назначения. Научные основы, технологии, рецептуры. СПб. : ГИОРД, 2015. 360 с.

11. Bystrická J., Musilová J., Lichtnerová H., Lenková M., Kovarovič J., Chalas M. The content of total polyphenols, ascorbic acid and antioxidant activity in selected varieties of quince (Cydonia oblonga Mill.) // Potravinarstvo Slovak Journal of Food Sciences. 2017. Vol. 11. № 1. P. 77-81. doi: 10.5219/699

12. Monka A., Grygorieva O., Chlebo P., Brindza J. Morphological and antioxidant characteristics of quince (Cydonia oblonga Mill.) and chinese quince fruit (Pseudocydonia sinensis Schneid.) // Potravinarstvo Slovak Journal of Food Sciences. 2014. Vol. 8. № 1. P. 333-340. doi: 10.5219/415

13. Лебедева Д.Д., Трусов Н.А., Соломонова Е.В., Ноздрина Т.Д., Меер Т.П. Перспективы использования хвойных растений Московского региона в качестве биобезопасного источника аскорбиновой кислоты // Вестник Курской государственной сельскохозяйственной академии. 2018. № 8. С. 31-35.

14. Митрофанова Д.Б., Соломонова Е.В., Трусов Н.А. Возможность использования шишкоягод тиса в пищевой промышленности // Евразийское научное объединение. 2018. № 5-4 (39). С. 197-198.

15. Ноздрина Т.Д., Трусов Н.А., Солнышкова А.А., Соломонова Е.В. Плоды бересклетов как источник масел // День науки : общеуниверситетская научная конференция молодых ученых и специалистов. М. : МГУПП, 2016. С. 81-82.

16. Чернов И.А., Ноздрина Т.Д., Трусов Н.А., Соломонова Е.В. Биоресурсный потенциал плодов Quercus для использования в пищевой промышленности // Материалы VI Международной научно-практической конференции «Проблемы современной биологии», посвященной 130-летию со дня рождения Н.И. Вавилова. ЛНР. Луганск : Изд-во ЛНАУ, 2017. С. 84-85.

17. Solomonova E.V., Trusov N.A., Nozdrina T.D. Opportunities for using of Eleutherococcuses fruits as a new food raw material // Advances in Biological Sciences Research. 2019. Vol. 7. P. 303-307. doi: 10.2991/ isils-19.2019.73

18. Solomonova E.V., Trusov N.A., Nozdrina T.D., Meer T.P., Sorokopudov V.N., Georgescu C. Food potential of alternative pome fruit trees cultivated in Moscow region // Scientific Study \& Research Chemistry \& Chemical Engineering, Biotechnology, Food Industry. 2019. Vol. 20 (4). P. 597—607.

19. Ноздрина Т.Д., Соломонова Е.В., Трусов Н.А. Нетрадиционные для Московского региона виды шиповников: морфометрические и весовые характеристики циннародиев // Социально-экологические технологии. 2019. Т. 9. № 2. С. 145-161. doi: 10.31862/2500-2961-2019-9-2-145-161. 


\section{Об авторах:}

Соломонова Екатерина Владимировна — кандидат биологических наук, преподаватель Государственного бюджетного профессионального образовательного учреждения города Москвы «Московский образовательный комплекс ЗАПАД», 121359, Российская Федерация, г. Москва, ул. Бобруйская, д. 23; e-mail: solomonova_k@mail.ru ORCID ID: 0000-0003-0061-4080

Трусов Николай Александрович — кандидат биологических наук, старший научный сотрудник лаборатории дендрологии Федерального государственного бюджетного учреждения науки Главный ботанический сад им. Н.В. Цицина Российской академии наук, 127276, Российская Федерация, г. Москва, ул. Ботаническая, д. 4; e-mail: n-trusov@mail.ru ORCID ID: 0000-0002-5147-6602

Ноздрина Татьяна Дмитриевна — кандидат биологических наук, доцент кафедры ветеринарно-санитарной экспертизы и биологической безопасности Федерального государственного бюджетного образовательного учреждения высшего образования Московский государственный университет пищевых производств, 125080, Российская Федерация, г. Москва, Волоколамское шоссе, д. 11; e-mail: biomgupp@yandex.ru ORCID ID: 0000-0003-2589-4787 